\title{
KEMATANGAN KARIR SISWA MADRASAH ALIYAH NEGERI (MAN) CIKARANG
}

\author{
Sri Mulyani ${ }^{1}$ \\ Th. I. Setiawan ${ }^{2}$ \\ Dede Rahmat Hidayat ${ }^{3}$
}

\begin{abstract}
Abstrak
Penelitian ini bertujuan untuk mengetahui kematangan karir siswa Madrasah Aliyah Negeri (MAN) Cikarang. Populasi penelitian ini adalah 606 siswa. Teknik sampling yang digunakan dalam penelitian ini adalah Simple random sampling dengan jumlah sampel 103 siswa. Skala yang digunakan adalah skala likert. Hasil penelitian menunjukan siswa yang memiliki kategori tinggi berjumlah 22 orang dengan persentase $21,4 \%$, siswa yang memiliki kategori sedang berjumlah 66 orang dengan persentase $64,0 \%$ dan kategori rendah dengan jumlah 15 orang dan persentase sebesar 14,6\%. Kesimpulan penelitian ini adalah kematangan karir siswa Madrasah Aliyah Negeri (MAN) Cikarang berada pada kategori sedang, hal ini dapat terlihat bahwa aspek yang banyak dipilih adalah aspek eksplorasi karir.
\end{abstract}

Kata Kunci : Kematangan Karir, siswa MAN Cikarang

Pendahuluan

Siswa tingkat SLTA, membutuhkan informasi yang berkaitan dengan karir setelah mereka lulus dari sekolah. Informasi tersebut perlu disampaikan dengan cara yang tepat sehingga siswa dapat memahaminya. Salah satu faktor yang menjadi masalah adalah karena pada saat mereka memilih sekolah menengah (SMA/SMK/MA) atau memilih jurusan ketika kuliah tidak sesuai dengan kepribadiannya sehingga mereka sulit untuk berada didunia seharusnya mereka bekerja yang sesuai dengan disiplin ilmu mereka.

Kematangan karir merupakan kesesuaian antara perilaku karir individu dengan perilaku karir yang diharapkan sesuai dengan tugas perkembangan. Kematangan karir merupakan tema sentral dalam teori perkembangan karir masa depan (life span career development) yang diperkenalkan oleh super. Super menyatakan bahwa kematangan karir didefinisikan sebagai kesiapan individu untuk membuat pilihan karir yang tepat.

Studi pendahuluan dilakukan pada minggu pertama bulan oktober ke beberapa siswa Madrasah Aliyah Negeri Cikarang melalui wawancara. Dari dua siswa Madrasah Aliyah Negeri Cikarang yang diwawancarai mengemukakan bahwa siswa tersebut merasa bingung dalam menentukan karir di masa datang. Pada dasarnya para siswa ingin mendapatkan pekerjaan yang baik dimasa datang, tapi karena biaya dan kemampuan dalam inteligensi kurang mendukung maka siswa merasa kurang percaya diri dalam menentukan karir dimasa datang.

Berkaitan dengan kondisi para siswa MAN Cikarang yang kebingungan dan kesulitan dalam mem-

1 Mahasiswa Jurusan Bimbingan dan Konseling FIP UNJ, moelyanie89@yahoo.com

2 Dosen Bimbingan dan Konseling FIP UNJ,

3 Dosen Bimbingan dan Konseling FIP UNJ, 
persiapkan dirinya untuk memilih keputusan karir pada jenjang menengah atas, hal ini karena para siswa kurang memahami dirinya dan karir yang akan dipilihnya. Oleh karena itu para siswa sekolah menengah atas perlu diberikan informasi atau penerangan tentang diri pribadinya dan karir yang akan dipilihnya.

\section{Kajian Teori \\ Karir}

Super memberikan definisi karir yaitu: "The sequence of occupations, job, and position occupied during the course of person's working life" (Dewa Ketut Sukardi, 1989). Definisi tersebut diartikan bahwa karir sebagai suatu rangka pekerjaan-pekerjaan, jabatan dan kedudukan yang mengarah pada kehidupan dalam dunia kerja Menurut Manrihu (1992) "Kematangan karir merupakan taraf perkembangan karir individu dalam suatu tahap atas dasar perbandingannya dengan kelompok seusianya dan yang diharapkan bagi usia tersebut". Maka dapat disimpulkan bahwa kematangan karir adalah suatu sikap yang dimiliki oleh seseorang (dalam hal ini adalah siswa) yang mampu menentukan pilihan karir yang sesuai dengan potensi dan kepribadian dirinya.

\section{Perkembangan Karir}

Super (dalam Manrihu, 1992) mengemukakan tentang perkembangan karir menjadi 5 tahap, yaitu:

1. Tahap pertumbuhan (growth stage) sejak lahir hingga usia 14 tahun

a. Prevokasional atau keingintahuan (0-4 tahun), tidak adanya minat ataupun keterlibatan dengan pilihan bidang karir. Tingkah laku didorong oleh kebutuhan dan keingintahuan.

b. Fantasi (4-10 tahun), yaitu khayalan menjadi dasar pemilihan bidang pekerjaan

c. Minat (11-12 tahun), hal-hal yang disukai menjadi determinan utama dari aspirasi dan aktivitas.

d. Kapasitas (13-14 tahun), kemampuan dan kapasitas menjadi dasar pertimbangan pemilihan karir.

2. Tahap Eksplorasi (exploration stage) pada usia 15-24 tahun

a. Subtahap sementara (tentative substage) usia
15-17 tahun, Kebutuhan, minat, kemampuan, dan nilai menjadi dasar bagi pemilihan bidang pekerjaan

b. Subtahap transisi (transition substage) usia 18-21 tahun, Ketika seseorang memasuki pasar tenaga kerja atau mencari kesempatan kerja menjadi ciri pemikirannya

c. Subtahap ujicoba (transition substage) usia 22-24 tahun, Suatu awal ditemukanya peran pekerjaan yang dirasa sesuai oleh seseorang dan dicobakan sebagai suatu potensi pekerjaan seumur hidup.

3. Tahap pembangunan (estabhlisment substage) usia 25-44 tahun

a. Subtahap uji coba (triat substage) usia 25-30 tahun, Satu atau dua perubahan karir mungkin menandai periode ini, tetapi ada komitmen yang lebih besar terhadap pekerjaan. Bagi beberapa orang, bisa saja menjadi jelas bahwa pekerjaan merupakan suatu seri atau bagian dari pekerjaan-pekerjaan yang tidak berhubungan.

b. Subtahap stabilisasi (stabilization substage) usia 31-44 tahun, ketika pola karir menjadi lebih jelas, seseorang berusaha untuk membuat tempat yang nyaman bagi dirinya dalam dunia kerja. Untuk sebagian orang saat ini merupakan waktu untuk mengembangkan kreativitas dan memperoleh promosi

4. Tahap pemeliharaan (maintenance stage) usia 45-64 tahun, Perhatian utama seseorang pada masa ini adalah pada kelanjutan dari pekerjaan yang dipilihnya, berpegang pada hasil-hasil yang diperoleh.

5. Tahap penurunan (decline stage) dimulai sejak 65 tahun

a. Subtahap pertambatan (deceleration substage) usia 65-70 tahun, Merupakan saat penurunan aktivitas kerja. Beberapa orang melakukan kerja paruh waktu untuk menggantikan kerja purna waktu.

b. Subtahap pension (retirement substage) dimulai sejak usia 71 tahun, Berdasarkan aktivitas kerja secara mudah, sulit, atau melalui kematian. 
Hendriati Agustiani (2009) mengemukakan proses perubahan yang dialami oleh remaja:

a. Perubahan fisik, rangkaian perubahan yang paling jelas yang Nampak dialami oleh remaja adalah perubahan biologis dan fisiologis yang berlangsung pada masa pubertas atau pada awal masa remaja, yaitu sekitar umur 11-15 tahun pada wanita dan 12-16 tahun pada pria.

b. Perubahan emosionalitas, Akibat langsung dari perubahan fisik dan hormonal tadi adalah perubahan dalam aspek emosionalitas pada remaja sebagai akibat dari perubahan fisik dan hormonal tadi, dan juga pengaruh lingkungan yang terkait dengan perubahan badani tersebut

c. Perubahan kognitif, semua perubahan fisik yang membawa implikasi perubahan emosional tersebut makin dirumitkan oleh fakta bahwa individu juga sedang mengalami perubahan kognitif. Perubahan dalam kemampuan berfikir ini diungkapkan oleh Piaget sebagai tahap terakhir yang disebut sebagai tahap formsl operation dalam perkembangan kognitif

d. Implikasi psikososial, semua perubahan yang terjadi dalam waktu singkat itu membawa akibat bahwa fokus utama dari perhatian remaja adalah dirinya sendiri

\section{Definisi Kematangan Karir}

Kematangan karir (career maturity) didefinisikan sebagai kesuaian antara perilaku karir individu dengan perilaku yang diharapkan pada usia tertentu di setiap tahap. Crites dalam Uman Suherman berpendapat, (2009) "The maturity of an individual's vocational behavior as indicated by the similarity between his behavior and that of the oldest individual's in his vocational stages". Definisi ini lebih menekankan kepada kematangan karir sebagai tahapan hidup (life-stages).

\section{Komponen Kematangan Karir}

1. Perencanaan karier, Beberapa aktivitas untuk membantu perencanan karier adalah: memahami tentang informasi karier, berbicara dengan baik tentang perencanaan karier, mengambil kursus untuk membantu menentukan karier, berpartisipasi dalam kegiatan ekstrakurikuler, bekerja paruh waktu dan mengikuti pelatihan serta pendi- dikan. Pendidikan yang dikehendaki, pandangan tentang dunia kerja, mendekati perbedaan untuk memasuki dunia kerja. Perencanaan karier lebih kepada sejauh mana siswa merasa ia tahu tentang berbagai macam aktivitas, bukan hanya sejauh mana ia tahu saja.

2. Eksplorasi karier, Eksplorasi karier membahas tentang pemikiran dan karier masa depan, dimana yang sebelumnya berkaitan dengan sumbersumber kerja.

3. Pembuatan keputusan, Konsep ini berkaitan dengan kemampuan dalam menggunakan pengetahuan untuk membuat perencanaan karier, dalam indicator pembuatan keputusan siswa diletakkan dalam situasi yang didalamnya terdapat pilihanpilihan karier dan memilih pilihan karier yang sesuai dengan dirinya sehingga individu mengetahui bagaimana cara mengambil keputusan. Pembuatan keputusan ini berdasarkan pemikiran individu merencanakan kariernya.

4. Informasi dunia kerja, konsep ini terdiri dari 2 elemen dasar;

a) Berkaitan dengan pengetahuan mengenai tugas-tugas perkembangan yang penting seperti, orang-orang harus mengeksplorasi kesenangan dan kemampuan mereka bagaimana orang belajar mengenal pekerjaan mereka dan alasan mengapa orang-orang berganti pekerjaan.

b) Meliputi pengetahuan mengenai tugas-tugas kerja dalam beberapa pekerjaan yang dipilih dan pengaplikasian tingkah laku kerja.

5. Pengetahuan minat kelompok pekerjaan, Dalam inventori perkembangan karir biasanya siswa diminta untuk memilih duapuluh kelompok profesi pekerjaan yang mereka minati, kemudian mereka ditanya mengenai hal-hal yang berkaitan dengan kelompok pekerjaan yang telah pilih seperti tentang, tugas-tugas dalam pekerjaan tersebut, dan peralatan dan syarat fisik dari pekerjaan. Mereka diminta untuk menilai kemampuan diri sendiri yang mencakup Sembilan kemampuan, yaitu kemampuan verbal dan non verbal, penalaran, kemampuan berhitung, kemampuan berbahasa, kemampuan mekanik, kemampuan spasial, kemampuan motorik, keterampilan bahasa inggris, kemampuan mengetik, dan kemampuan membaca. Mereka menganalisa Sembilan kemampuan 
yang ada pada dirinya, sehingga mereka dapat mengetahui minat pekerjaan yang sesuai dengan kemampuannya.

6. Realisme, pada dasarnya tidak diuji dalam inventori perkembangan karir. Super menggambarkan realisme sebagai perpaduan antara kognitif dan kesatuan afektif. Realisme mengggambarkan gabungan antara afektif dan kognitif dinilai sebagai kesatuan yang baik dari individu, self report, dan data objektif sebagai pembanding antara bakat diri dengan tipe-tipe bakat dalam suatu pekerjaan

7. Orientasi karir, Merupakan istilah yang meliputi konsep kematangan karir yaitu perencanaan karir, eksplorasi karir, pembuatan keputusan, informasi dunia kerja, pengetahuan minat kelompok pekerjaan, dan realisme. Perencanaan karir dan eksplorasi karir merupakan sikap perkembangan karir. Sedangkan pembuatan keputusan dan informasi dunia kerja merupakan pengetahuan perkembangan karir dan keterampilan.

\section{Metode Penelitian}

Penelitian ini menggunakan jenis penelitian kuantitatif. Metode penelitian deskriptif dengan jenis penelitian survey. Penelitian ini bertujuan untuk memperoleh data informasi tentang kematangan karir siswa MAN Cikarang Utara.. Pelaksanaan penelitian ini dilaksanakan di Madrasah Aliyah Negeri Cikarang Utara yang bertempat di kota Cikarang Utara kabupaten Bekasi. Penelitian ini dilakukan selama bulan Oktober sampai dengan Maret 2014. Populasi dalam penelitian ini adalah seluruh siswa Madrasah Aliyah Negeri Cikarang Utara yang berjumlah 606 siswa. Jumlah sampel yang diambil adalah $15 \%$ dari jumlah populasi yaitu $15 \%$ dari 606 orang seba-nyak 103 orang. Teknik yang digunakan dalam penelitian ini adalah Simple Random Sampling. peneliti menggunakan kuesioner. Pada penelitian ini, kuesioner yang disebar menggunakan skala Likert. Pada skala Likert, digunakan empat kategori pilihan jawaban, yaitu selalu (SL), sering (SR), kadangkadang (KD), dan tidak pernah (TP). Peneliti telah melakukan uji coba instrument pada minggu kedua bulan februari 2014 terhadap 30 responden di Madrasah Aliyah Swasta di Cikarang. Skor tiap item dikonsultasikan dengan $\mathrm{r}$ tabel Product Moment dengan taraf kesalahan 0,5 \%, item yang digunakan pada instrument alat ukur berjumlah 27 butir yang valid dan 15 butir yang drop dan diperoleh reliabelitas 0,764 . Analisis data yang digunakan adalah Statistik deskriptif. Rumus yang digunakan adalah rumus Mean.

\section{Hasil dan Pembahasan}

Berdasarkan data yang diperoleh, maka dapat dilihat skor terendah 52 dan tertinggi 100, dengan Mean sebesar 76,81553, reliabilitas sebesar 0,764 dan modus sejumlah 84 dan median 77. Sedangkan simpangan baku sebesar 9,86 dan variansnya sebesar 97,27. Selanjutnya untuk menentukan interpretasi dari skor yang di peroleh, maka skor yang ada di distribusikan dengan menggunakan kategorisasi yang di buat dengan kelas interval. Untuk lebih jelasnya dapat dilihat tabel berikut ini:

Tabel 1. Kategori Kematangan Karir Siswa MAN Cikarang

\begin{tabular}{|c|c|c|c|}
\hline Kategorisasi & Rentang Skor & Frekuensi & $\%$ \\
\hline Tinggi & $86.68-106.40$ & 22 & $21.4 \%$ \\
\hline Sedang & $66.95-86.68$ & 66 & $64.0 \%$ \\
\hline Rendah & $47.23-66.95$ & 15 & $14.6 \%$ \\
\hline \multicolumn{2}{|c|}{ Jumlah } & 103 & $\mathbf{1 0 0 \%}$ \\
\hline
\end{tabular}

Berdasarkan hasil di atas, diperoleh data bahwa persentase menunjukkan siswa MAN Cikarang berada pada kategori sedang dengan jumlah persentase sebesar 64,0\% dengan jumlah siswa yang memiliki kematangan pada kategori sedang adalah 66 orang. Pada kategori tinggi, jumlah persentasenya sebesar $21,40 \%$ dengan jumlah siswa 22 orang dan pada kategori rendah sebesar $14,60 \%$ dengan jumlah siswa 15 orang.

Data Kematangan karir keseluruhan

\begin{tabular}{|c|c|c|c|c|c|c|c|c|c|c|c|c|}
\hline \multirow{3}{*}{\begin{tabular}{|l|} 
VARIABEL \\
Kematangan
\end{tabular}} & \multirow{2}{*}{\multicolumn{2}{|c|}{$\begin{array}{l}\text { Perencanaan } \\
\text { karir }\end{array}$}} & \multirow{2}{*}{\multicolumn{2}{|c|}{$\begin{array}{l}\text { Eksplorasi } \\
\text { Karir }\end{array}$}} & \multirow{2}{*}{\multicolumn{2}{|c|}{\begin{tabular}{|c|} 
Pengambilan \\
Keputusan
\end{tabular}}} & \multirow{2}{*}{\multicolumn{2}{|c|}{$\begin{array}{l}\text { Informasi } \\
\text { kerja }\end{array}$}} & \multirow{2}{*}{\multicolumn{2}{|c|}{\begin{tabular}{|c|}
$\begin{array}{c}\text { Pengetahuan } \\
\text { Minat }\end{array}$ \\
Kelompok \\
Pekerjaan \\
\end{tabular}}} & \multirow{2}{*}{\multicolumn{2}{|c|}{ Jumlah }} \\
\hline & & & & & & & & & & & & \\
\hline & $\mathrm{F}$ & $\%$ & $\mathrm{~F}$ & $\%$ & $\mathrm{~F}$ & $\%$ & $\mathrm{~F}$ & $\%$ & $\mathrm{~F}$ & $\%$ & $\mathrm{~F}$ & $\%$ \\
\hline Karir & 629 & 21,9317 & 958 & 33,4031 & 404 & 14,0865 & 435 & 15,1674 & 442 & 15,4114 & 2868 & 100 \\
\hline
\end{tabular}

Dapat dilihat dari data yang telah diperoleh, bahwa aspek yang memiliki jumlah skor dan persentase paling tingi adalah pada aspek eksplorasi karir de- 
ngan jumlah skor sebesar 958 dan jumlah persentase adalah 33 \%. Hal ini menunjukkan siswa MAN Cikarang berada pada aspek ekslporasi karir.

\section{Data Kematangan Karir Berdasarkan Aspek 1. Aspek Perencanaan Karir}

Aspek perencanaan karir

\begin{tabular}{|c|c|c|c|}
\hline Kategorisasi & Rentang Skor & \% & F \\
\hline Tinggi & $23.14-28.79$ & $23.302 \%$ & 24 \\
\hline Sedang & $17.50-23.14$ & $66.990 \%$ & 69 \\
\hline Rendah & $11.85-17.50$ & $9.708 \%$ & 10 \\
\hline \multicolumn{2}{|c|}{ Jumlah } & $\mathbf{1 0 0 \%}$ & $\mathbf{1 0 3}$ \\
\hline
\end{tabular}

Jumlah persentase dengan kategori tinggi adalah $23,302 \%$, jumlah persentase pada kategori sedang adalah 66,99\% dan persentase pada kategori rendah adalah 9,708 \%. Berdasarkan data di atas, maka pada aspek perencanaan karir, siswa MAN Cikarang berada pada kategori sedang, hal ini berkesinambungan pada aspek secara keseluruhan bahwa pada asapek perencanaan karir memiliki hasil sebesar $21,9317 \%$

\section{Aspek Eksplorasi Karir}

Aspek eksplorasi karir

\begin{tabular}{|c|c|c|c|}
\hline Kategorisasi & Rentang Skor & \% & F \\
\hline Tinggi & $37.63-48.72$ & $21.359 \%$ & 22 \\
\hline Sedang & $26.54-37.63$ & $66.019 \%$ & 68 \\
\hline Rendah & $15.45-26.54$ & $12.622 \%$ & 13 \\
\hline \multicolumn{2}{|c|}{ Jumlah } & $\mathbf{1 0 0 \%}$ & $\mathbf{1 0 3}$ \\
\hline
\end{tabular}

Maka hasil pada aspek ekplorasi karir ini berada pada kategori sedang dengan jumlah persentase sebesar $66,019 \%$ dengan jumlah siswa yang memiliki kategori sedang pada aspek eksplorasi karir sebanyak 68 siswa.

\section{Aspek Pengambilan Keputusan}

aspek pengambilan keputusan

\begin{tabular}{|c|c|c|c|}
\hline Kategorisasi & Rentang Skor & \% & F \\
\hline Tinggi & $4.18-6.09$ & $45.631 \%$ & 47 \\
\hline Sedang & $2.28-4.18$ & $47.573 \%$ & 49 \\
\hline Rendah & $0.38-2.28$ & $6.796 \%$ & 7 \\
\hline \multicolumn{2}{|c|}{ Jumlah } & $100 \%$ & $\mathbf{1 0 3}$ \\
\hline
\end{tabular}

Pada aspek pengambilan keputusan, diperoleh data bahwa siswa MAN Cikarang lebih banyak berada pada kategori sedang dengan jumlah persentase sebesar 47,573 \% atau jumlah siswa nya sebanyak 49 orang. Sedangkan siswa yang berada pada kategori tinggi sebesar 45,631\% atau jumlah sisiwanya sebanyak 47 orang. dan siswa yang memiliki kategori rendah adalah $6,7961 \%$ atau sebanyak 7 orang

\section{Aspek Informasi Dunia Kerja}

\section{aspek informasi dunia kerja}

\begin{tabular}{|c|c|c|c|}
\hline Kategorisasi & Rentang Skor & \% & F \\
\hline Tinggi & $7.85-11.03$ & $48.544 \%$ & 50 \\
\hline Sedang & $4.67-7.85$ & $43.689 \%$ & 45 \\
\hline Rendah & $1.49-4.67$ & $7.767 \%$ & 8 \\
\hline \multicolumn{2}{|c|}{ Jumlah } & $100 \%$ & $\mathbf{1 0 3}$ \\
\hline
\end{tabular}

Pada aspek informasi dunia kerja berada pada kategori tinggi. Dengan jumlah siswa pada kategori tinggi sebanyak 50 siswa dengan persentase sebesar 48,544 \%, siswa dengan kategori sedang berada pada persentase 43,689\% dengan jumlah siswa sebanyak 45 orang dan siswa pada kategori rendah memiliki persentase sebesar $7,767 \%$ dengan jumlah siswa sebanyak 8 orang

\section{Aspek Pengetahuan Minat Kelompok Pekerjaan}

\begin{tabular}{|c|c|c|c|}
\hline Kategorisasi & Rentang Skor & $\%$ & $\mathbf{F}$ \\
\hline Tinggi & $17.96-24.24$ & $35.922 \%$ & 37 \\
\hline Sedang & $11.67-17.96$ & $55.341 \%$ & 57 \\
\hline Rendah & $5.39-11.67$ & $8.737 \%$ & 9 \\
\hline \multicolumn{2}{|c|}{ Jumlah } & $100 \%$ & 103 \\
\hline
\end{tabular}

Pada aspek ini terlihat bahwa siswa MAN Cikarang berada pada kategori sedang dengan persentase $55,341 \%$ dengan jumlah siswa sebanyak 57 orang, siswa yang berada pada kategori tinggi sebanyak 37 orang dengan persentase sebanyak 35,92\% dan siswa pada kategori rendah sebanyak 9 orang dan persentasenya sebesar $8,737 \%$

\section{Kesimpulan dan Saran}

Hasil penelititian ini adalah bahwa siswa Madrasah Aliyah Negeri Cikarang memiliki kematangan karir yang sedang. Uraiannya sebagai berikut, jumlah responden 22 yang memiliki skor pada instrument penelitian antara 66,95 sampai 86,68 berada pada kategori tinggi dengan persentase $21,4 \%$. Sedangkan skor pada instrument penelitian anta- 
ra 86,68 sampai 106,40 yang memiliki 66 responden dan kategorinya adalah sedang dengan persentase $64,0 \%$. Pada kategori rendah terdapat 15 responden yaitu dengan skor instrument penelitian antara 47,23 sampai 66,95 dan persentasenya sebesar 14,6 \%. Dengan demikian tingkat kematangan karir siswa Madrasah Aliyah Negeri Cikarang adalah kategori sedang dengan persentase sebesar $64,0 \%$.

Saran-saran yang dapat menjadi pertimbangan berdasarkan hasil penelitian ini adalah:

1. Bagi siswa, diharapkan para siswa dapat memanfaatkan sumber-sumber dan sarana yang tersedia baik di sekolah, rumah ataupun di masyarakat.

2. Bagi guru pembimbing, diharapkan para guru pembimbing MAN Cikarang dapat membantu siswa-siswi MAN Cikarang dalam meningkatkan kematangan karir dengan berbagai cara, salah satunya dapat mengadakan career day.

3. Peneliti selanjutnya. Semoga penelitian ini dapat menjadi bahan masukan dan pembanding dalam melakukan penelitian terbaru mengenai kematangan karir siswa.

\section{Daftar Pustaka}

Dewa Ketut Sukardi 1989. Pendekatan Konseling Karir dalam Bimbingan Karir. Satu Pendahuluan. Jakarta: Ghalia Indonesia

Manrihu, M.T. 1992. Pengantar Bimbingan dan konseling karir. Jakarta. Bumi aksara.

Richard S. 1992. Applying career Development Theory to Counseling. University of Delaware cole Publishing Company. California

Sugiono. 2008. Metode penelitian pendidikan. Bandung : Alfabet.

Uman Suherman. 2009. Konsep Dan Aplikasi Bimbingan Dan Konseling 2008. Bandung. Universitas Pendidikan Indonesia.

Hendriati Agustiani. 2009. Psikologi Perkembangan (Pendekatan Ekologi Kaitannya dengan Konsep Diri dan Penyesuaian diri pada Remaja). Bandung: PT.Refika Aditama 